\title{
Purchase Decision on Green Coffee Shop: The Role of Green Promotion, Green Physical Evidence, and Environmental Awareness
}

\author{
Cempaka Paramita ${ }^{1}$, Farhana Zia ${ }^{2,}$, R. Andi Sularso ${ }^{3}$ \\ ${ }^{1}$ Faculty of Economics and Business, University of Jember, Jember, Indonesia \\ ${ }^{2}$ Faculty of Economics and Business, University of Jember, Jember, Indonesia \\ ${ }^{3}$ Faculty of Economics and Business, University of Jember, Jember, Indonesia \\ *Corresponding author. Email: farhanazia284@gmail.com
}

\begin{abstract}
The objective of this study is to examine the effect of green promotion, green physical awareness, and environmental awareness on purchase decision at green coffee shop named Retrorika Coffee Bar and Resto Malang. The sample consisted of 160 respondents taken by applying purposive sampling technique. Data were analyzed using multiple linear regression analysis. The results show that, first, green promotion has a positive and significant effect on purchase decision. Retrorika Coffee Bar and Resto Malang strives to carry out environmental campaigns to consumers both online and offline. Second, green physical evidence has a positive and significant effect onpurchase decision. Retrorika Coffee Bar and Resto Malang strives to use environmentally friendly tools so that consumers feel safe and comfortable and interested in making purchase decision. Third, environmental awareness has a positive and significant effect on purchase decision. Consumers make purchase decision since they have great environmental awareness, in line with the products and services offered by the Retrorika Coffee Bar and Resto Malang.
\end{abstract}

Keywords: Environmental Awareness, Green Physical Evidence,Green Promotion, Purchase Decision

\section{INTRODUCTION}

According to Sustainable Waste Indonesia (SWI) data [1], the current management of all types of waste ending up in Final Disposal Sites (TPA) is 69\%, dumping waste or waste directly on the ground without a permit (illegal dumping). by $24 \%$, and for waste or recycled waste only $7 \%$. This data has evidence that the waste or waste that is recycled by people in Indonesia is not comparable to what ends up in the landfill. By 2025, SWI predicts that waste will be well managed. This is because the National Policy and Strategy (JAKSTRANAS) regarding waste management will be increased by $70 \%$ for the waste handling target and $30 \%$ for the waste decomposition target [1]. Based on these data, it can be seen that some people have the awareness to carry out consumption activities without destroying nature by managing the waste that has been produced. [2], argues that people who care about environmental sustainability will change their consumption behavior, such as buying products that are more environmentally friendly. This is in accordance with the opinion of [3], stating that the decision made by consumers to make purchase decision based on environmental criteria attached to the product is called green consumption. This opinion is supported by [4], which states that green consumption is usually related to consumption responsibility towards the environment where consumers consider the environmental impact of buying, using, and disposing of various products, or using various green services.

According to [5], a program that refers to the environment of the task of process management to meet consumer demands and needs by responding to requests from consumers who behave in green consumption is called green marketing. The term green marketing developed in the late 1980s and early 1990s when the American Marketing Association (AMA) held its first 
seminar with the theme "ecological marketing". [6], defines green marketing as something that consists of all activities designed to generate and facilitate any exchange intended for human needs or wants, so that the satisfaction of needs and wants can occur with minimal harm to the natural environment. In implementing a green marketing strategy the company must be able to integrate environmental issues into the company's marketing mix [7]. According to [8], the marketing mix is a set of marketing tools used as a company strategy consisting of product, price, place, promotion, people, physical evidence, and process. Green marketing mix is part of the marketing mix which has an additional function, namely to keep the environment friendly.

Consumers who have environmental awareness will decide to buy products that are environmentally friendly. According to [8], purchase decision are how individuals, groups, and organizations choose, buy, use, and how goods, services, ideas or experiences to satisfy their needs and desires. The application of green promotion and green physical evidence in cafes will influence purchase decision from consumers who have environmental awareness. This is because the information and convenience obtained by consumers will be a consideration for consumers in making a purchasing decision on a product that has a positive value to the environment.

According to [8]-[11], who examined the effect of environmental awareness on purchase decision showed the same results, namely that environmental awareness had a positive and significant influence on purchase decision. Research on green physical evidence is still relatively small, so researchers use elements of the marketing mix as a reference in this study. In the research of [12], which examines the influence of elements of the marketing mix (product, price, place, promotion, people, process, and physical environment) on purchase decision, shows that there is a positive and significant influence partially and simultaneously from marketing mix elements on decisions purchase. This opinion is supported by [13], who examine the effect of physical evidence on purchase decision, showing that there is a positive influence of physical evidence on purchase decision. In the research of [14] and [15], who examined the effect of green products, green prices, green places, and green promotions on decisionspurchasing, shows that there is a positive and significant effect of green product, green price, green place, and green promotion on purchase decision. This is different from research by [16], which examines the effect of the green marketing mix on purchase decision which shows that the green marketing mix (green product, green price, and green place) has a positive influence on purchase decision while green promotion does not. has a positive influence on purchase decision.

This research tries to offer new insight toward green marketing theory and application, especially related to the effect green promotion, green physical evidence, and environmental awareness on purchase decision due to several reasons. First, the number of studies on green physical evidence focusing on green coffee shop is still relatively limited. Second, researchers are interested in conducting a study by combining the variables of green promotion, green physical evidence, and environmental awareness of the dependent variable of purchase decision. According to the empirical studies on previous research, not much have examined the combination of three proposed variables, green promotion, green physical evidence, and environmental awareness and its effects on purchasing decision. Third, the object used by the researcher is different from previous research.

Some examples of the companies implementing green marketing in Indonesia are KFC, The Body Shop, and Starbucks. Based on information obtained from [17], currently $\mathrm{KFC}$ is promoting organic rice. It aims to attract consumers who are enjoying green consumption. The strategy used by KFC is in the form of a green product strategy, where the company sells a product that does not have a negative impact on the environment. Furthermore, based on data obtained from [18]. The Body Shop is a type of beauty product that is famous for its natural ingredients in the manufacturing process. This is because The Body Shop follows the current beauty trend, namely back to nature. As in the case of KFC, where this company also sells a green product, but at The Body Shop the products sold are in the form of cosmetics. This will certainly attract consumers who have green consumption behavior to buy beauty products from The Body Shop.The next company, namelyStarbucks, one of which is located in Malang. Based on research conducted by [19], that this coffee shop was created through a commitment to the use of appropriate materials and waste disposal. Starbucks uses campaign tools to attract consumers by providing information about the right way to reduce waste and how to recycle it. Therefore, Starbucks became one of the competitors of the object of research studied by researchers.

This research focused on local coffee shop, named Retrorika Coffee Bar and Resto Malang, that implements green marketing strategy. This coffee shop offers 
something unique and interesting which is located in Bumiaji Village, Batu Tourism City. This coffee shop uses recycled goods as room decoration. In addition to a unique and attractive coffee shop atmosphere, an ecofriendly concept is also applied in this coffee shop. This coffee shop does not provide tissue, plastic straws, or other materials containing plastic, but it does provide substitute items such as cloth rags, stainless straws, and bamboo baskets for take-out food products. If visitors want to buy drinks take away or take home, then there is an additional fee to buy glass bottles as beverage packaging. To attract consumer in making purchase decision, this café has consistently applied green marketing strategy in term of doing green promotion and providing green physical evidences. These strategies, together with consumer environmental awareness, are some antecedents of purchase decision toward green coffee shop. According to [8], purchase decisions are how individuals, groups, and organizations choose, buy, use, and how goods, services, ideas or experiences to satisfy their needs and desires. [20], state that the purchase decision is a choice that has been selected from two or more alternative choices. Based on this opinion, it can be concluded that the purchase decision is a decision taken by consumers in choosing one option from several alternative choices they have.

\subsection{The Effect of Green Promotion on Purchase Decision}

Green promotion is a company's effort to provide actual information about a product to consumers and make consumers interested in knowing more about this information. According to [21], green promotion is a marketing promotion strategy that is associated with environmental issues so that customers can distinguish it from promotions from other products. In the results of research conducted by [14], shows that the green promotion variable has a positive influence on purchase decisions while according to [16], green promotion does not have a positive influence. Based on the proposed theory and previous research results, the research hypothesis is as follows:

$\mathrm{H}_{1}$ : Green promotion has a positive and significant effect on purchase decision

\subsection{The Effect of Green Physical Evidence on Purchase Decision}

[22], who argue that the concept related to nature is based on the interest of an environmental conservation community which aims to involve the community to be closer to nature as a way to increase awareness of the surrounding environment. This opinion is supported by [23], who argues that green physical evidence must ensure that the place has a reforestation system so that it must be applied from a holistic point of view. Green physical evidence is the physical aspect of a company that is friendly to the environment. In the results of research conducted by [12] and [13], shows that the physical evidence variable has a positive influence on purchase decisions. According to the previous explanation, the research hypotheses is as follows:

$\mathrm{H}_{2}$ : Green physical evidence has a positive and significant effect on purchase decision

\subsection{The Effect of Environmental Awareness on Purchase Decision}

Environmental awareness is one of the components that shows the individual's environmental responsibility [24]. According to [25], people who have a strong awareness will buy environmentally friendly products so that it is related to their goal to protect the environment. According to [26], environmental support behavior is defined as an action by an individual or group that promotes the results of the sustainable use of natural resources. Environmental awareness is an understanding of each individual to maintain and preserve the surrounding environment. This statement is supported by [27], which states that consumers carry out a series of consumption activities to express their environmental responsibility and to achieve environmental sustainability. The results of research conducted by [9], [10], [11], and [28] show that environmental awareness has a significant influence on purchase decisions. Based on the relevant theory and previous research results, the research hypothesis is as follows:

$\mathrm{H}_{3}$ : Environmental awareness has a positive and significant effect on purchase decision.

Based on the description of the relationship between green promotion, green physical evidence, environmental awareness, and purchase decision, the conceptual framework of this research is presented in Figure 1. 


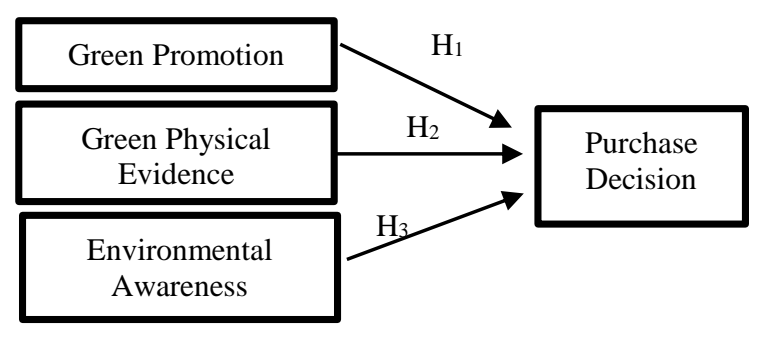

Figure 1. Conceptual Framework

\section{METHOD}

This research is explanatory research. According to [29], explanatory research aims to explain the variables studied and the relationship between one variable and another and test the formulated hypothesis. The population determined in this study was consumers who have made purchases at Retrorika Coffee Bar and Resto Malang. The sample consisted of 160 respondents obtained from the distribution of questionnaires distributed directly by visiting respondents and online via Google Form. This study used purposive sampling based on the following criteria: (1)respondents who are at least 18 years old, which according to [30], respondents aged 18 years is considered to have stable emotions and can think rationally as consumers in making purchase decision and also that they can understand and answer research questions well, (2)respondents were the consumers who have made at least two purchases, and (3)respondents have already know the concept of green marketing as applied by Retrorika Coffee Bar and Resto Malang. Before distributing the questionnaire, the researcher will conduct interviews and confirm to the respondents regarding the concept of green marketing and environmental awareness. Research data were analyzed using multiple regression analysis run by IBM SPSS 23 .

\section{RESULTS AND DISCUSSIONS}

\subsection{Respondent Characteristics}

Based on the characteristics of the respondents, it can be concluded that the majority of consumers are male $(54.4 \%)$, aged $18-25$ years $(48.8 \%)$, high school and college students $(43.1 \%)$, and have visited Retrorika Coffee Bar and Resto Malang 4 times a year (42.5\%). Detail description of respondents characteristics is provided in Table 1.
Table 1. Description of Respondent Characteristics

\begin{tabular}{|c|c|}
\hline Characteristic & Amount and Percentage \\
\hline Gender & $\begin{array}{l}\text { a. Male: } 87(54.4 \%) \\
\text { b. Female: } 73(45.6 \%)\end{array}$ \\
\hline Age & $\begin{array}{l}\text { a. } 18-25 \text { years old: } 78(48.8 \%) \\
\text { b. } 26-45 \text { years old: } 51(31.9 \%) \\
\text { c. } 46-65 \text { years old: } 31(19.4 \%)\end{array}$ \\
\hline Occupation & 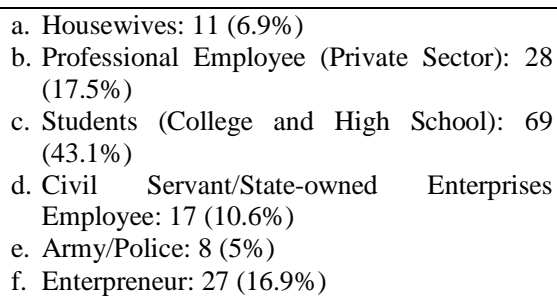 \\
\hline Annual Visits & $\begin{array}{l}\text { a. } 3 \text { times: } 43(26.9 \%) \\
\text { b. } 4 \text { times: } 68(42.5 \%) \\
\text { c. } 5 \text { times: } 27(16.9 \%) \\
\text { d. }>5 \text { times: } 22(13.8 \%)\end{array}$ \\
\hline
\end{tabular}

\subsection{Validity and Reliability Tests}

Based on the results of the validity test (using Pearson's Product Moment Coefficient $r$ with the decision criteria, namely if $r$ count $>r$ table $(0.154)$ and the significant value is less than 5\%), and reliability test (with a minimum value of Cronbach's Alpha 0.6), 16 items statement of the 4 research variables proved valid and reliable. This is indicated by the calculated $r$ value of $0.689-0.848$, the significant value is 0.000 , and the Cronbach's Alpha value is $0.718-0.857$. The results of the validity and reliability test are presented in Table 2.

Table 2. Results of Validity and Reliability Tests

\begin{tabular}{|c|c|c|c|c|}
\hline Variable & Item & $\mathbf{r}_{\text {statistics }}$ & Sig. & $\begin{array}{c}\text { Cronbach's } \\
\text { Alpha }\end{array}$ \\
\hline \multirow{4}{*}{$\mathrm{X}_{1}$} & $\mathrm{X}_{1.1}$ & 0.777 & 0.000 & \multirow{4}{*}{0.791} \\
\hline & $\mathrm{X}_{1.2}$ & 0.805 & 0.000 & \\
\hline & $\mathrm{X}_{1.3}$ & 0.757 & 0.000 & \\
\hline & $X_{1.4}$ & 0.798 & 0.000 & \\
\hline \multirow{4}{*}{$\mathrm{X}_{2}$} & $\mathrm{X}_{2.1}$ & 0.730 & 0.000 & \multirow{4}{*}{0.718} \\
\hline & $\mathrm{X}_{2.2}$ & 0.689 & 0.000 & \\
\hline & $\mathrm{X}_{2.3}$ & 0.747 & 0.000 & \\
\hline & $\mathrm{X}_{2.4}$ & 0.775 & 0.000 & \\
\hline \multirow{5}{*}{$\mathrm{X}_{3}$} & $\mathrm{X}_{3.1}$ & 0.781 & 0.000 & \multirow{5}{*}{0.857} \\
\hline & $\mathrm{X}_{3.2}$ & 0.756 & 0.000 & \\
\hline & $\mathrm{X}_{3.3}$ & 0.761 & 0.000 & \\
\hline & $\mathrm{X}_{3.4}$ & 0.841 & 0.000 & \\
\hline & $\mathrm{X}_{3.5}$ & 0.848 & 0.000 & \\
\hline \multirow{3}{*}{$\mathrm{Y}$} & Y.1 & 0.774 & 0.000 & \multirow{3}{*}{0.727} \\
\hline & $Y .2$ & 0.831 & 0.000 & \\
\hline & $\mathrm{Y} .3$ & 0.809 & 0.000 & \\
\hline
\end{tabular}




\subsection{Normality Test}

Based on the results of the normality test (using Kolmogrov Smirnov with a significance level $(\alpha)>5 \%$ ), the 4 research variables were normally distributed. This is indicated by the asymp sig value of $0.055-0.120$. The results of the normality test are shown in Table 3.

Table 3. Results of Data Normality Test

\begin{tabular}{|c|c|}
\hline Variable & Asymp Sig. \\
\hline $\mathrm{X}_{1}$ & 0.083 \\
\hline $\mathrm{X}_{2}$ & 0.058 \\
\hline $\mathrm{X}_{3}$ & 0.120 \\
\hline $\mathrm{Y}$ & 0.055 \\
\hline
\end{tabular}

\subsection{Results of Multiple Regression Analysis}

Based on the results of multiple regression analysis, the resulting regression model is as follows:

$$
Y=0.557+0.353 X 1+0.285 X 2+0.233 X 3+e
$$

From the above equation, a constant value of 0.557 means that if the value of the green promotion variable (X1), green physical evidence (X2) and environmental awareness (X3) is equal to zero, the purchase decision (Y) is a constant 0.557 .

The coefficient value of the green promotion variable is positive 0.353 , which means that each increase in one unit of the green promotion variable (X1) will increase purchase decision by 0.353 with the assumption that green physical evidence (X2) and environmental awareness (X3) remain. The coefficient value of the green physical evidence variable is positive 0.285 which every one unit increase in the green physical evidence variable (X2) will increase purchase decision by 0.285 with the assumption that green promotion (X1) and environmental awareness (X3) remain. The coefficient value of the environmental awareness variable is positive 0.233 , which means that each increase in one unit of the environmental awareness variable (X3) will increase purchase decision by 0.233 with the assumption that green promotion (X1) and green physical evidence (X2) remain. The results of multiple linear regression analysis are presented in Table 4.

Table 4. Results of Multiple Regression Analysis

\begin{tabular}{|c|c|c|c|}
\hline Variable & $\begin{array}{c}\text { Regression } \\
\text { Coefficient }\end{array}$ & Sig. & Description \\
\hline Constant & 0.557 & - & - \\
\hline $\mathrm{X}_{1}$ & 0.353 & 0.000 & Significant \\
\hline $\mathrm{X}_{2}$ & 0.285 & 0.001 & Significant \\
\hline $\mathrm{X}_{3}$ & 0.233 & 0.001 & Significant \\
\hline
\end{tabular}

\subsection{Classical Assumption Test}

\subsubsection{Model Normality Test}

Based on the results of the model normality test (using graphic analysis) the green promotion variable (X1), green physical evidence (X2) and environmental awareness (X3) on purchase decision (Y) which shows that the data points show data that spreads around the diagonal line and following the direction of the diagonal line can be interpreted that the regression model meets the assumption of normality. The results of the model normality test are presented in Figure 2 below.

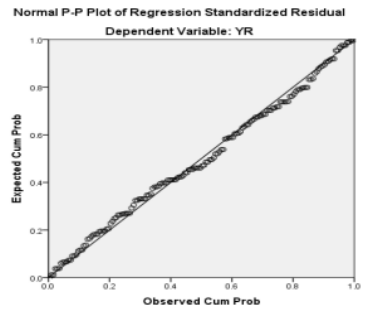

Figure 2. Results of Normality Test

\subsubsection{Results of Multicollinearity Test and Heteroscedasticity Test}

Based on the results of the multicollinearity test (VIF value $<10$ and tolerance value close to 1 or $>0.1$ ) and heteroscedasticity test (significance value $>5 \%$ ), it can be interpreted that the green promotion variable (X1), green physical evidence (X2) and environmental awareness (X3) on purchase decision (Y) there is no multicollinearity and heteroscedasticity. It is shown that each variable has a VIF value of less than 10 and a tolerance value of more than 0.1 , and a significant value of $>5 \%$. The results of the multicollinearity test and the heteroscedasticity test are presented in Table 5 .

Table 5. Results of Multicollinearity Test and Heteroscedasticity Test

\begin{tabular}{|c|c|c|c|}
\hline \multirow{2}{*}{ Variable } & \multicolumn{2}{|c|}{ Collinearity Statistics } & \multirow{2}{*}{ Sig. } \\
\cline { 2 - 3 } & VIF & Tolerance & \\
\hline $\mathrm{X}_{1}$ & 3.302 & 0.303 & 0.967 \\
\hline $\mathrm{X}_{2}$ & 3.394 & 0.295 & 0.919 \\
\hline $\mathrm{X}_{3}$ & 3.016 & 0.332 & 0.167 \\
\hline
\end{tabular}




\subsection{Results of Hypothesis Testing}

\subsection{1 t Test}

Based on the results of the t test (significance value < $5 \%$ ) and the regression coefficient, which is positive, it can be interpreted that the green promotion variable (X1), green physical evidence (X2) and environmental awareness (X3) are significant and have positive influence on purchase decision (Y). The detailed results of the $t$ test can be seen in Table 6 .

Table 6. Results of t Test

\begin{tabular}{|c|c|c|c|}
\hline Variable & $\begin{array}{c}\text { Regression } \\
\text { Coefficient }\end{array}$ & Sig. & Conclusion \\
\hline $\mathrm{X}_{1}$ & 0.353 & 0.000 & $\mathrm{H}_{1}$ accepted \\
\hline $\mathrm{X}_{2}$ & 0.285 & 0.001 & $\mathrm{H}_{2}$ accepted \\
\hline $\mathrm{X}_{3}$ & 0.233 & 0.001 & $\mathrm{H}_{3}$ accepted \\
\hline
\end{tabular}

\subsubsection{Coefficient Determination Test}

Based on the results of the coefficient of determination ( $\mathrm{R} 2$ value between $0-1$ ), it can be seen that the $\mathrm{R}$ value (correlation coefficient number) of 0.835 indicates that there is a direct relationship between green promotion (X1), green physical evidence (X2) and environmental awareness (X3). on purchase decision (Y) is $83.5 \%$. While the value of R2 ( $\mathrm{R}$ Square) shows that the amount of direct influence between green promotion (X1), green physical evidence (X2) and environmental awareness (X3) on purchase decision (Y) is $69.5 \%$ so that the remaining $30.5 \%$ is explained by variables outside the research model. The results of the coefficient of determination test are presented in Table 7.

Table7.Results of Coefficient Determination Test

\begin{tabular}{|l|l|l|l|l|}
\hline $\begin{array}{c}\text { Mode } \\
\text { l }\end{array}$ & \multicolumn{1}{|}{$\mathbf{R}$} & $\begin{array}{c}\text { RSquar } \\
\text { e }\end{array}$ & $\begin{array}{c}\text { Adjusted } \\
\text { R Square }\end{array}$ & $\begin{array}{c}\text { Std. Error } \\
\text { of the } \\
\text { Estimate }\end{array}$ \\
\hline 1 & $.835^{\mathrm{a}}$ & .697 & .691 & .382052 \\
\hline
\end{tabular}

\subsection{Discussion}

Green promotion has an effect on purchase decision at Retrorika Coffee Bar and Resto Malang as evidenced by the results of the $t$ test which shows the significance value is smaller than the specified significance level $(0.000<0.05)$. A positive regression coefficient value indicates that the better the green promotion, the purchase decision will increase. These results are in accordance with the research conducted by [22], which shows that the green promotion variable has a positive and significant influence on purchase decision and rejects the results of [16], which shows that green promotion does not have a positive influence on purchase decision.

Green physical evidence has an effect on purchase decision at Retrorika Coffee Bar and Resto Malang as evidenced by the results of the $t$ test which shows a significance value smaller than the specified significance level $(0.001<0.05)$. A positive regression coefficient value indicates that the better the green physical evidence, the purchase decision will increase. These results are in accordance with research conducted by [12] and [13], which shows that the green physical evidence variable has a positive and significant influence on purchase decision.

Environmental awareness has an effect on purchase decision at Retrorika Coffee Bar and Resto Malang as evidenced by the results of the $t$ test which shows the significance value is smaller than the specified significance level $(0.001<0.05)$. A positive regression coefficient value indicates that the better the environmental awareness, the purchasing decision will increase. These results are in accordance with research conducted by [9], [10], [11], and [29] showing that environmental awareness has a positive and significant influence on purchase decision.

\section{CONCLUSION}

Green promotion has a positive and significant effect on purchase decision. Retrorika Coffee Bar and Resto Malang seeks to conduct environmental campaigns to consumers both online and offline. Green physical evidence has a positive and significant effect on purchase decision. Retrorika Coffee Bar and Resto Malang strives to use environmentally friendly tools so that consumers feel safe and comfortable so that consumers are interested in making purchase decision at the cafe. Environmental awareness has a positive and significant effect on purchase decision. Consumers of Retrorika Coffee Bar and Resto Malang choose this cafe as a place to relax to make a decision to buy their products rather than other cafes because the theme used is natural nuanced which shows the support for the importance of environmental awareness.

Based on the results of this study, the manager of Retrorika Coffee Bar and Resto Malang needs to increase green promotion efforts, green physical evidence and environmental awareness to improve purchase decision, the main thing is on green promotion because this variable has a fairly good response from 
respondents among the other two variables. Further researchers can add independent variables to determine other factors that influence consumer purchase decision, such as green products, green prices, or other elements of the green marketing mix.

\section{REFERENCES}

[1] Katadata.co.id, Menuju Indonesia Peduli Sampah [Internet], 2019 [updated 2020 Sep 28; cited 2019 Desember 10], Available from: https://katadata.co.id/timpublikasikatadata/infografi k/5e9a4c4a336e0/menuju-indonesia-peduli-sampah

[2] Hussain, M. A., M. F. Khokhar, and A. Asad, "Green Awareness Effects on Consumer's Purchase decision: A Case of Pakistan," Global Journal of Management and Business Research,14(6): 9-15, 2014.

[3] Peattie, K. Environmental Marketing Management: Meeting the Green Challenge. New Jersey: Prentice Hall,1995.

[4] Moisander, J, "Motivational Complexicity of Green Consumerism," International Journal of Consumer Studies, 31(4): 404-409, 2007.

[5] Paco, D. A. M. F., Raposo, M. L. B., and Filho, W. L. "Identifying The Green Consumer: A Segmentation Study," Journal of Targeting, Measuring, and Analysis for Marketing, 17(2): 17-25, 2009.

[6] Polonsky and M. Jay, "An Introduction to Green Marketing," Electronic Green Journal, 1(2), 1994.

[7] Sumarwan, A. G. Ujang, A. W. Prihartono, D. A. Sumarlin, E. Mamahit, H. Purnomo, J. Hasan, M. Ahmady, R. Wulandari, and T. Haryono, Riset Pemasaran dan Konsumen. Bogor: PT. Penerbit IPB Press, 2012.

[8] Kotler, Philip, and G. Armstrong, Prinsip-Prinsip Pemasaran. Edisi Ketiga Belas. Jilid 1. Jakarta: Erlangga. 2016.

[9] Mika, S. M. D. S, "PengaruhGreen Awareness terhadap Keputusan Pembelian Produk Organik," Mini Thesis. Malang: Universitas Brawijaya, 2017.

[10] Syahrivar, J, "Pengaruh Kesadaran Lingkungan Terhadap Keputusan Pembelian Kosmetik Ramah Lingkungan Di Kawasan Industri Cikarang.” Jurnal Manajemen, 7(1): 74-92, 2017.
[11] Lestari, N. I, "Pengaruh Green Awareness terhadap Keputusan Pembelian Produk Kosmetik Ramah Lingkungan Konsumen Generasi Y," Jurnal Ekonomi Vokasi. 3(10): 36-48, 2020.

[12] Panjaitan, et al, "The Effect of Marketing Mix on Consumer Purchase Decision on Bright Gas Product in Medan (Study in OT. Pertamina (Persero) Marketing Operation Region I," International Journal of Research and Review, 6(10): 205-212, 2019.

[13] Sara, F. M., Ningsih, C., and Andari, R, "Pengaruh Physical Evidence terhadap Keputusan Pembelian Konsumen di Coffee shop Infinito Culinery Bandung," Gastronomy Tourism Journal, 3(2): 6-18, 2017.

[14] Nashrulloh, M. A., Budiantono, B., and Wulandari, W. "Analisis Pengaruh Green Marketing Mix terhadap Keputusan Pembelian Lampu LED Philips (Studi pada Konsumen Di Desa Kesiman, Kecamatan Trawas)," In Conference on Innovation and Application of Science and Technology (CIASTECH), 2(1): 1-10, 2019.

[15] Putra, I. K, “ Pengaruh Green Marketing Terhadap Keputusan Pembelian Produk The Body Shop Pada Konsumen Tunjungan Plaza Kota Surabaya," Skripsi. Jember: Fakultas Ekonomi dan Bisnis Universitas Jember, 2011.

[16] Wulandari, P., and Widodo, A. "Pengaruh Green Marketing Mix terhadap Keputusan Pembelian dalam Memilih Produk Elektronik," E-Proceedings of Management, 5(1): 1033-1040, 2018.

[17] Tribunnews.com, KFC Galakkan Beras Organik [updated 2020 Nov 18], Available from: https://www.tribunnews.com/bisnis/2012/07/06/kfcgalakkan-beras-organik

[18] Stylo.grid.id, Terkenal denhan Bahan Alami The Body Shop Indonesia Turut Merayakan Hari Vegetarian Sedunia, 2018 [updated 2020 Nov 18; cited 2018 Oktober 3], Available from : https://stylo.grid.id/read/14949292/terkenal-denganbahan-alami-the-body-shop-indonesia-turutmerayakan-hari-vegetarian-sedunia?page=all

[19] Sari, I. G. A. W., and Setiawan, P. Y "Pengaruh Green Marketing dan Packaging terhadap Brand Image dan Loyalitas pelanggan pada konsumen 
Starbucks Coffee," E-Jurnal Manajmen Universitas Udayana, 6(7): 3820-3849, 2017.

[20] Sciffman, L. G. and L. L. Kanuk, Consumer Behavior. New Jersey: Prentice Hall, 2009.

[21] Praharjo, A, "Pengaruh Green Advertising terhadap Persepsi tentang Green Brand dan Keputusan Pembelian (Survei pada Mahasiswa Fakultas Ilmu Adminisitrasi Angkatan 2010/2011 Universitasi Brawijaya Konsumen Air Minum Kemasan Merek ADES,”Jurnal Administrasi Bisnis, 4(2): 1-9, 2013.

[22] Soga, M. and K. J. Gaston, "Extinction of Experience: The Loss of Human-Nature Interactions," Frontiers in Ecology and The Environment, 14(2): 94-101, 2016.

[23] Larashati, H., H. Hudrasyah, dan N. Chandra, "7Ps of Green Marketing as Factors Influencing Willingness to Buy Towards Environmentally Friendly Beauty Products," In Proceedings of International Conference on Business Management and IS. 1(1): 277-282, 2012.

[24] Thompson Jr, J. C. and E. L Gasteiger, "Environmental Attitude Survey of University Students: 1971 vs 1981," The Journal of Environmental Education, 17(1): 13-22, 1985.

[25] Xu, L., V. Prybutok, and C. Blankson, "An Environmental Awareness Purchasing Intention Model," Industrial Management and Data Systems, 119(2): 367-381, 2019.

[26] Sivek, D. L. and H. R. Hungerford, "Predictors of Responsible Environmental Behaviour: an Analysis," Journal of Environmental Education, 21(2): 35-40, 1989.

[27] McDonald, S. dan C. J. Oates, "Sustainability: Consumer Perceptions and Marketing Strategies. Business Strategy and The Environment," 15(3): 157170, 2006.

[28] Rumpoko, U. A. D, "Pengaruh Green Awareness terhadap Keputusan Pembelian Produk Ramah Lingkungan," Skripsi. Yogyakarta: Universitas Negeri Yogyakarta, 2016.

[29] Sugiyono, Metode Penelitian Kombinasi (Mix Method). Bandung: Alfabeta, 2015.
[30] Hartono, J, Metodologi Penelitian Bisnis: Salah Kaprah dan Pengalaman-pengalaman. Yogyakarta: BPFE, 2004. 